\title{
Is tourism affecting polychaete assemblages associated with rhodolith beds in Northeastern Brazil?
}

\author{
Dimítri de Araújo Costa ${ }^{1}$, Francisco de Assis da Silva ${ }^{2}$, José Marcelino de Lima Silva ${ }^{3}$, Amaury \\ Ramos Pereira ${ }^{4}$, Marina Dolbeth ${ }^{5}$, Martin Lindsey Christoffersen ${ }^{6}, \&$ \\ Reinaldo Farias Paiva de Lucena ${ }^{7}$
}

1. Regional Program of Post-Graduation in Development and Environment (PRODEMA), Federal University of Paraíba (UFPB), Brazil. Interdisciplinary Centre of Marine and Environmental Research (CIIMAR), University of Porto, Portugal; dimitri.costa@ciimar.up.pt, costa.researcher@yahoo.com.br

2. Regional Program of Post-Graduation in Development and Environment (PRODEMA/UFPB), Brazil; assismandela@gmail.com

3. Program of Post-Graduation in Environmental Education (IESP/UNAVIDA), Brazil. Superintendency of Environmental Management of the State of Paraíba (SUDEMA), Brazil; jmarcelinopescador@hotmail.com

4. Government of the State of Paraíba, Brazil, amaurysoledade@yahoo.com.br

5. Interdisciplinary Centre of Marine and Environmental Research (CIIMAR), University of Porto, Portugal, mdolbeth@ciimar.up.pt,marinadolbeth@gmail.com

6. Department of Systematics and Ecology (DSE), Center of Exact and Nature Sciences (CCEN), Federal University of Paraíba, Brazil; mlchrist@dse.ufpb.br

7. Department of Systematics and Ecology, Center of Exact and Nature Sciences, Federal University of Paraíba; Regional Program of Post-Graduation in Development and Environment (PRODEMA/UFPB), Brazil; rlucena@dse.ufpb.br

Received 19-VII-2018. Corrected 06-II-2019. Accepted 30-VI-2019.

\begin{abstract}
Introduction: Rhodoliths are biogenic structures distributed worldwide, formed by several types of calcareous algae. They may host a great diversity of marine invertebrates, among which polychaetes are conspicuous and diversified representatives. Rhodolith beds are notwithstanding vulnerable to several human activities (e.g. exploitation of commercial species associated with rhodoliths, petroleum exploration, fishing activities, effluent discharges, and tourism), which may compromise that diversity. Tourism is presently increasing its impact on rhodolith beds. Global warming and ocean acidification are also determinant factors in faunal change. Objective: to analyse the polychaete assemblages associated with rhodolith beds subject to different intensities of touristic pressure at Seixas Beach (NE Brazil), where tourism is gradually increasing over time. Methods: Effects were evaluated at two depths, $1.5 \mathrm{~m}$ and $4.0 \mathrm{~m}$. Sampling was done every two months during 2015, encompassing the two marked seasons of the year in the region (rainy and dry). Quadrats of $15 \times 15 \mathrm{~cm}$ were placed in each depth during sampling. All rhodoliths present within the quadrat were collected (usually four to five rhodoliths). Our hypothesis was that the deeper depth and the samples from the dry season months would be increasingly subject to the impact of tourism. Results: Overall, 49 species were found (from 21 different families), and a total of 733 individuals were collected. The most abundant species was Eunice wasinensis (280 individuals, $38.2 \%$ of total abundance). The species Eurythoe complanata, Eunice biannulata, E. wasinensis, Lysidice ninetta, Oxydromus pugettensis and Ceratonereis (Ceratonereis) singularis appeared in all months. The study detected a tendency for higher diversity to occur at the depth of $1.5 \mathrm{~m}$ for all indices, but only the Shannon-Wiener values were significantly higher there $(\mathrm{p}<0.05)$. No clear differences were found regarding
\end{abstract}

Costa, D. A., Silva, F. A., Silva, J. M. L., Pereira, A. R., Dolbeth, M., Christoffersen, M. L., \& Lucena, R. F. P. (2019). Is tourism affecting polychaete assemblages associated with rhodolith beds in Northeastern Brazil? Revista de Biología Tropical, 67(S5) Suplemento, S1-S15. 
months or season. Conclusions: These results suggest that a higher potential pressure due to tourism may occur at $4.0 \mathrm{~m}$ due to more intense craft shipping activities (traffic of catamaran boats transporting tourists to and from the reefs) in that area.

Key words: Annelida, Catamarans, Disturbance, Hard substrate, Tropical coast.

Rhodoliths are incrusting, non-articulate aggregates of calcareous algae that usually occur in shallow waters, providing hard substrate for other organisms (Foster et al., 2007; Amado-Filho et al., 2012). These algae retain calcium carbonate, and provide important information on paleoclimatic and paleoenvironmental conditions in a particular area (Amado-Filho \& Pereira-Filho, 2012; Aguirre, Braga, \& Bassi, 2017). Rhodolith banks are recorded from several regions in the world, mainly in the Gulf of California, in the Caribbean, along the Atlantic coast of Canada, in Great Britain, Norway, Japan, and Australia (Foster, 2001; Amado-Filho \& Pereira-Filho, 2012). In Brazil, they may represent the largest known depositional bank of $\mathrm{CaCO}_{3}$ worldwide (Amado-Filho et al., 2012).

Rhodoliths represent an important tridimensional, biogenic environment (Nelson, 2009; Otero-Ferrer et al., 2018), being known as "bioengineers" or "habitat modifiers" (Bruno \& Bertness, 2001). They provide shelter and food for a large diversity of benthic invertebrates (Riul, Lacouth, Pagliosa, Christoffersen, \& Horta, 2009; Amado-Filho \& Pereira-Filho, 2012). Bosence (1979) indicated that the internal morphology of some types of rhodoliths, which do not have interconnected inner branches, favor the colonization by polychaetes and mollusks.Thus, the conservation of rhodoliths guarantees the habitat of a large diversity of the marine fauna.

Previous work across the world has recurrently highlighted that this habitat holds a large diversity and quantities of marine invertebrates (e.g. Bosence, 1979; Giménez-Casalduero, Rodríguez-Ruiz, Vivas, \& Ramos-Esplá, 2001; Hinojosa-Arango \& Riosmena-Rodríguez,
2004; Metri, 2006; Prata, Costa, Manso, Crispim, \& Christoffersen, 2017; Otero-Ferrer et al., 2018), revealing the importance of these habitats as refuge sites for the young stages of mollusks and several commercial fishing stocks (Riosmena-Rodríguez et al., 2017). Rhodoliths may thus be considered hotspots of biodiversity. Although relatively resilient against environmental oscillations (Riosmena-Rodríguez, Nelson, \& Aguirre, 2017), rhodolith banks are extremely vulnerable to human activities, such as the extraction of commercial species associated with the rhodoliths, petroleum surveys and leakages, platform constructions, traffic of vessels (Horta et al., 2015), fishing activities, effluent discharges (Horta et al., 2016) and tourism. Besides, in the sphere of global ecological changes, global warming and ocean acidification can also affect rhodolith seabeds (Riosmena-Rodríguez et al., 2017). The impacts of these activities may contribute significantly to their survival but also to the loss of the associated diversity. Europe has implemented conservation measures that place the rhodolith habitat as a priority in the list of habitats requiring conservation, restoration and monitoring (OSPAR - Convention for the Protection of the Marine Environment of the North-East Atlantic) (Nelson, 2009; Instituto Brasileiro de Petróleo, Gás e Biocombustíveis [IBP], 2014). Rhodoliths have been included in a network of protection areas known as "Natura 2000" (Riosmena-Rodríguez et al., 2017). Despite these recognitions of the importance of rhodoliths and their associated species, in tropical zones such as the Brazilian coastline, conservation measures for rhodolith banks are still scarce (Horta et al., 2016). 
Polychaetes have an important role in trophic chains. They may occupy distinct niches and have a high diversity of species and distinct levels of tolerance to different types of pollution and environmental impacts. Polychaetes are thus considered good bioindicators of human-caused perturbations (Reish, 1979; Bellan, 1980; Samuelson, 2001; Berlandi, Figueiredo, \& Paiva, 2012). On the other hand, polychaetes represent up to about $70 \%$ of the benthic macrofaunal biomass of shelf environments. Consequently, they may reflect the general condition of the macrofauna (Knox, 1977; Paiva, 1993). Several studies use the assemblages of polychaetes to evaluate the state of ecosystems (Giangrande, Licciano, \& Musco, 2005), mainly in soft-bottom environments, but few in "hard-bottom" habitats (e.g. Bellan, 1980; Giangrande, Delos, Musco, Licciano, \& Pierri, 2004; Giangrande et al., 2005; Hinojosa-Arango \& Riosmena-Rodríguez, 2004), including rhodoliths (e.g. GiménezCasalduero et al., 2001; Berlandi et al., 2012). Such studies have revealed a high diversity of polychaetes inhabiting rhodolith seabeds, in particular specimens belonging to the families Eunicidae, Nereididae and Syllidae, but also some uncommon species (e.g. Amphicteis gunneri(M. Sars, 1835), Pherusa scutigera (Ehlers, 1887) and Phyllodoce schmardaei Day, 1963) (Giménez-Casalduero et al., 2001; Neves, 2011; Costa, 2016).

The present study analyzed the structure of the polychaete assemblage associated with rhodoliths in the reef environment at Seixas Beach, João Pessoa, Paraíba, in Northeast Brazil. The Seixas Beach is subjected to a high touristic pressure, mainly in the dry season, which has increased gradually over time (G1-Paraíba, 2016). Indeed, in the year 2015, the surrounding city of João Pessoa received around 1210000 tourists (G1-Paraíba, 2016). The beach also has coral reef areas, in depths between 3.0 to $6.0 \mathrm{~m}$ that are highly used as recreative areas. These activities result in the presence of numerous vessels (with a capacity of 100 people/vessel during the dry season, Melo, Lins, \& Eloy, 2014) and diving activities within those depths (Melo, Crispim, Lima, \& Nishida, 2006). We thus plan to evaluate comparatively the composition of the polychaete assemblages in rhodoliths at two depths (1.5 and $4.0 \mathrm{~m}$ ), and per month, that correspond to the two seasons of the year (January, September and November-dry season, and March, May and July-rainy season), to study the effect of pressure exerted by tourism. We hypothesized that increased tourism pressure occurs at the deepest $(4.0 \mathrm{~m})$ than in shallowest area $(1.5 \mathrm{~m})$, due to the presence of vessels and due to their use as a recreational diving area, and during the months of the dry season, which coincides with an increase in touristic activities.

\section{MATERIALS AND METHODS}

Study area and sampling: The study was conducted at Seixas Beach $\left(07^{\circ} 09^{\prime} \mathrm{S}\right.$ and $34^{\circ} 47^{\prime}$ $\mathrm{W})$, located on the coast of the State of Paraiba, Northeast Brazil. This region has an equatorial climate with a dry summer (Alvares, Stape, Sentelhas, Gonçalves, \& Sparovek, 2013). The rainy season lasts from March to August, with a total cumulative annual precipitation varying from 900 to $1800 \mathrm{~mm}$ (Lima \& Heckendorff, 1985). The annual temperature range is low, with temperatures varying between 24 and $27{ }^{\circ} \mathrm{C}$. The coastal reefs at Seixas Beach are located approximately $700 \mathrm{~m}$ from the shoreline, in the Municipality of João Pessoa (Melo, Crispim, Viana, \& Lins, 2008). Depth in the reef areas varies from 0.5 to $1.5 \mathrm{~m}$, during low tide, and from 3.0 to $6.0 \mathrm{~m}$ at high tides (Melo, Lins, \& Eloy, 2014). The latter depths become exposed to the turbulence provoked by vessels known as catamarans, which are largely used to transport tourists, and diving activities in the region in recent years.

Sampling took place during low tide in 2015, with a bimonthly periodicity (i.e., January, March, May, July, September and November), and at two depths, $1.5 \mathrm{~m}\left(07^{\circ} 09^{\prime} 13^{\prime \prime} \mathrm{S}\right.$ e $\left.34^{\circ} 47^{\prime} 21^{\prime \prime} \mathrm{W}\right)$ and $4.0 \mathrm{~m}\left(07^{\circ} 09^{\prime} 13^{\prime \prime} \mathrm{S}\right.$ and $\left.34^{\circ} 47^{\prime} 10^{\prime \prime} \mathrm{W}\right)$. As mentioned above, the depth $4 \mathrm{~m}$ is potentially more affected by tourism pressure than the area at $1.5 \mathrm{~m}$. An initial visual 
prospection also confirmed this trend. One quadrat of $15 \times 15 \mathrm{~cm}$ was placed in each depth at each sampling date and all rhodoliths present within the quadrat were collected (usually four to five rhodoliths), in a total of 12 samples. Samples were placed in bags and taken to the laboratory, where they were processed. First the calcareous algae were identified and then the rhodoliths were broken using a grinder, to remove the associated fauna. All polychaetes were removed, stored in $4 \%$ buffered formalin solution and washed in the laboratory. The specimens were then sorted and preserved in $70 \%$ ethanol, and subsequently identified to the highest possible taxonomic resolution and counted. Polychaetes were identified based on the specialized literature, e.g. Day (1967a, 1967b), Nonato \& Luna (1970), Fauchald (1977, 1992), Uebelacker \& Johnson (1984), Amaral \& Nonato (1994), Blake, Hilbig, \& Scott (1995, 1996, 1997), Camargo \& Lana (1995), Capa (2003), Santos \& Lana (2003), Viéitez et al. (2004), Barroso \& Paiva (2007), De Assis, Samiguel, \& Christoffersen (2007), Costa, De Assis, \& Christoffersen (2008) and Böggemann (2009).

Data Analyses: The following diversity indices were determined from the polychaete abundance matrix with the DIVERSE function in the PRIMER-PERMANOVA software: Species number (S); Shannon-Wiener diversity index $\left(\mathrm{H}^{\prime}, \log _{\mathrm{e}}\right.$ individual $\left.^{-1}\right)$; and Pielou's evenness index $(\mathrm{J})$. In addition, we checked the influence of tourism pressure on diversity index values, total abundance and polychaete assemblage composition, following an experimental design that does not use replication, and includes the factors "depth" (two fixed levels: $1.5 \mathrm{~m}$ and $4.0 \mathrm{~m}$ ) and "month" (six fixed levels: March, May, July, September, November and January). Exploratory analyses showed that data were not parametric (i.e., Shapiro-Wilk test, $\mathrm{p}<0.05$; Levene test, $\mathrm{p}<$ $0.05)$. Therefore, all analyses were performed with the 2-factor PERMANOVA procedure, which allows testing the influence of two factors in a crossed design for multivariate or univariate data (Anderson, Gorley, \& Clarke, 2008). We applied the PERMANOVA to test differences between depth and month for the assemblage total abundance, diversity indices, and species composition. Values of the assemblage abundance and diversity indices were converted into an Euclidean Distance similarity matrix. For the assemblage composition, the abundance per species matrix was converted into a Bray-Curtis similarity matrix, with a dummy variable to compensate for zero occurrences (Clarke, Gorley, Somerfield, \& Warwick, 2014). The tested data were further explored using Principal Coordinates Analyses (PCoA), to clarify patterns of change. All analyses were performed with the PRIMERPERMANOVA software (Clarke et al., 2014). In addition, Spearman correlation coefficients were calculated between the total abundance per depth and precipitation, using the library 'Hmisc', implemented in the $\mathrm{R}$ software ( $\mathrm{R}$ Core Team, 2018).

\section{RESULTS}

A total of 733 individuals, organized into 21 polychaete families, 36 genera, and 49 species were collected during 2015 at Seixas Beach (Table 1). A total of 445 individuals came from the station at the depth of $1.5 \mathrm{~m}$, while another 288 specimens were captured at $4.0 \mathrm{~m}$. This difference between sites was caused largely by the higher diversity and abundance obtained at $1.5 \mathrm{~m}$ in January. When grouped by season of the year, a total of 333 individuals were present in the dry season, against 440 for the rainy season. However, we did not find differences when comparing the total abundance for the two depths in the six months (2-way PERMANOVA, $p>0.01$, Table 2). Also, the variation of the abundance and precipitation along the year did not show a clear correlation for each of the tested depths (Spearman, $p>$ 0.2 ). The abundance peaked in January (dry season) at $1.5 \mathrm{~m}$ (182 individuals), while for $4.0 \mathrm{~m}$ the highest abundance was observed in March (rainy season, 109 individuals, Fig. 1). 


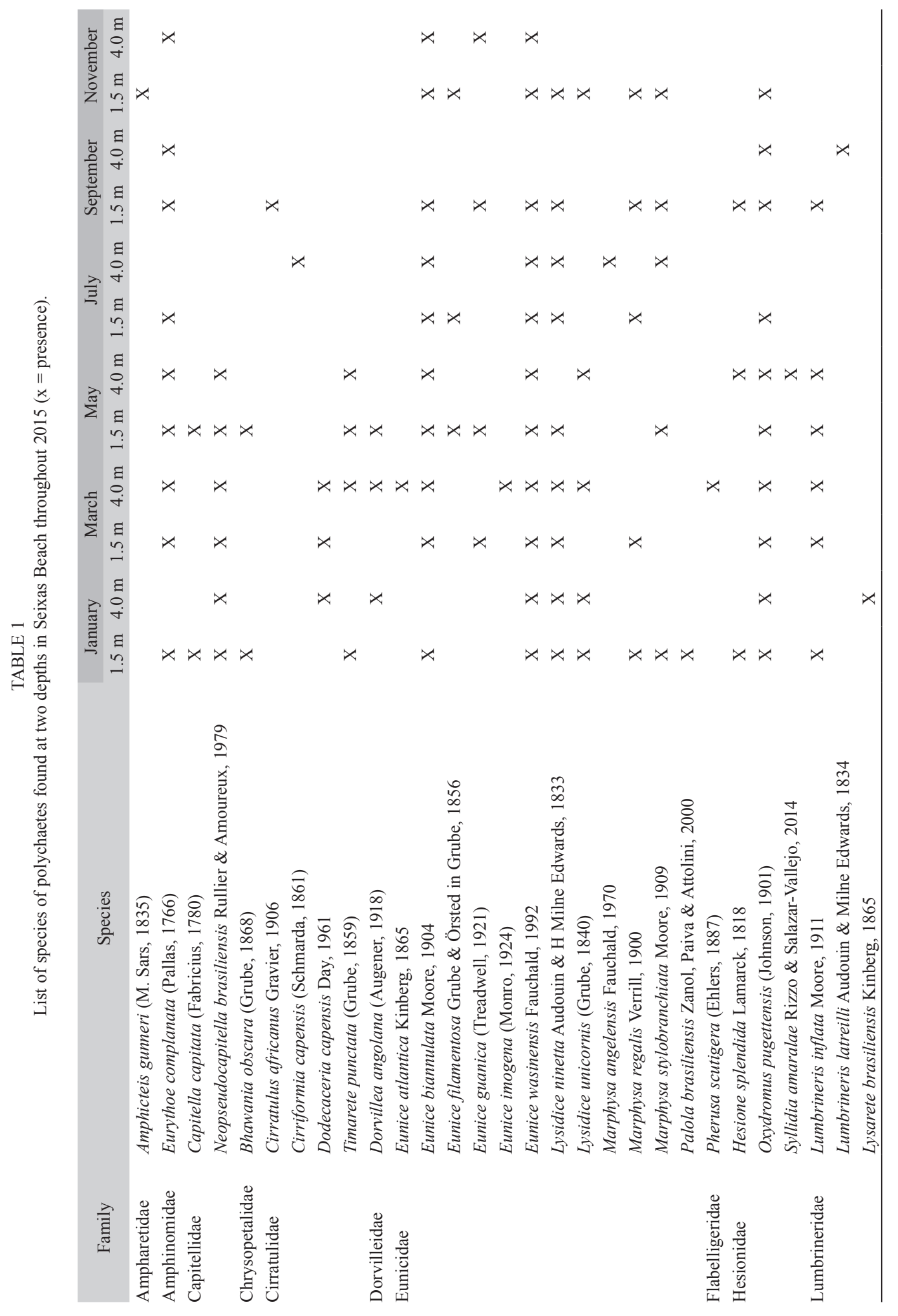

(c) (i) Rev. Biol. Trop. (Int. J. Trop. Biol. ISSN-0034-7744) Vol. 67(S5) Supplement: S1-S15, July 2019 


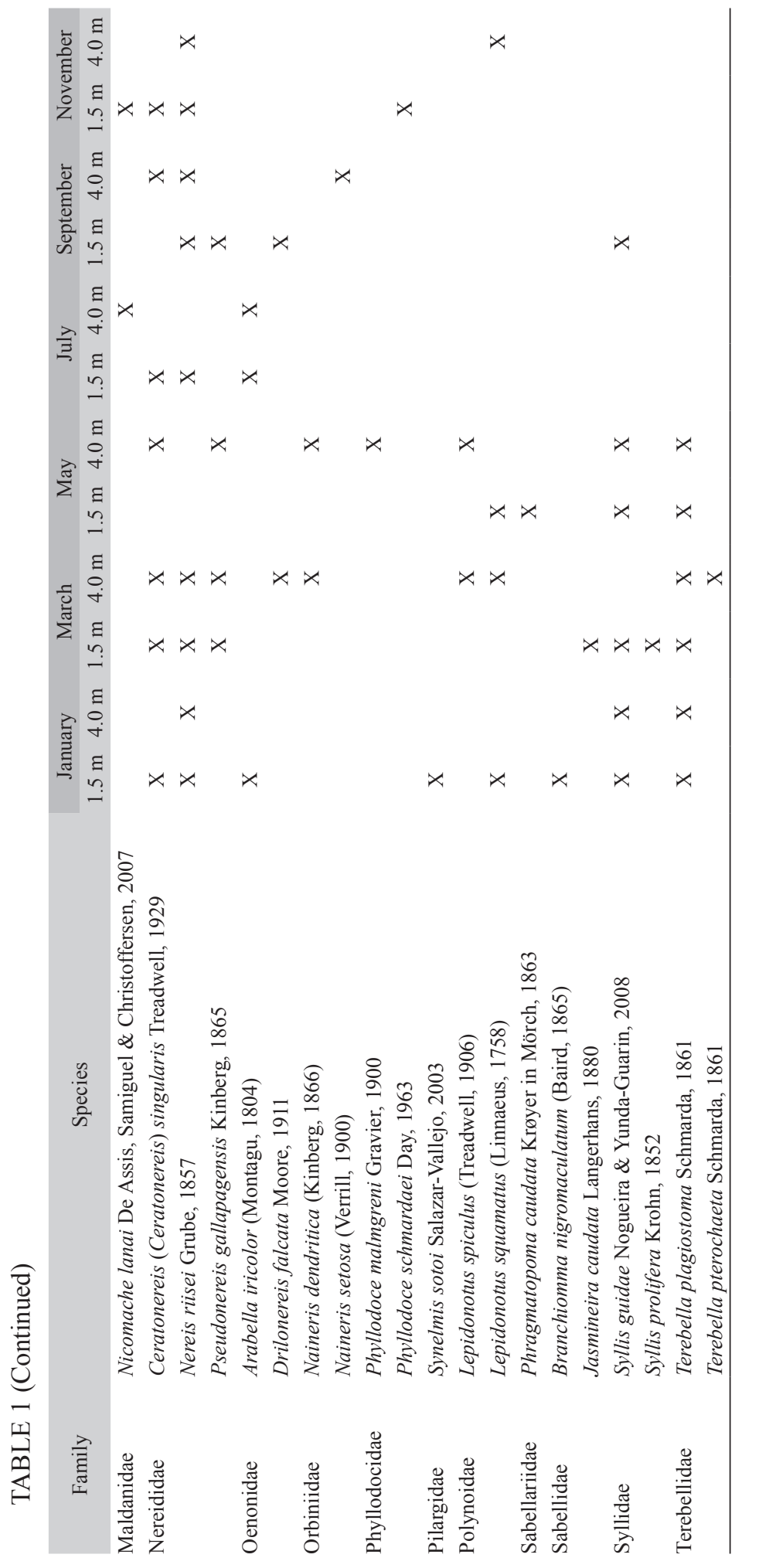

6

Rev. Biol. Trop. (Int. J. Trop. Biol. ISSN-0034-7744) Vol. 67(S5) Supplement: S1-S15, July 2019 (c) (i) 
A

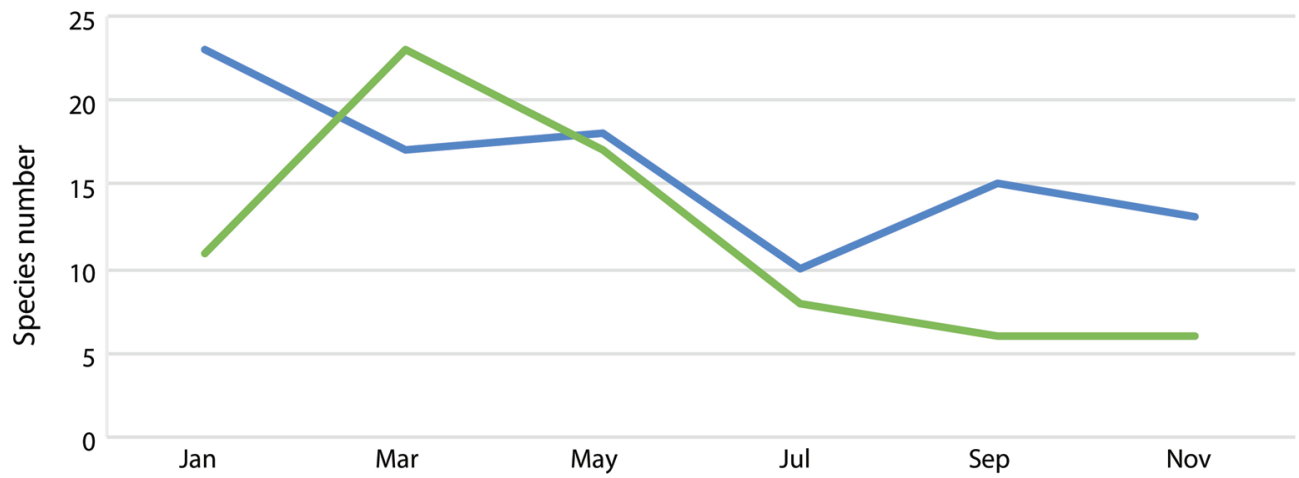

B

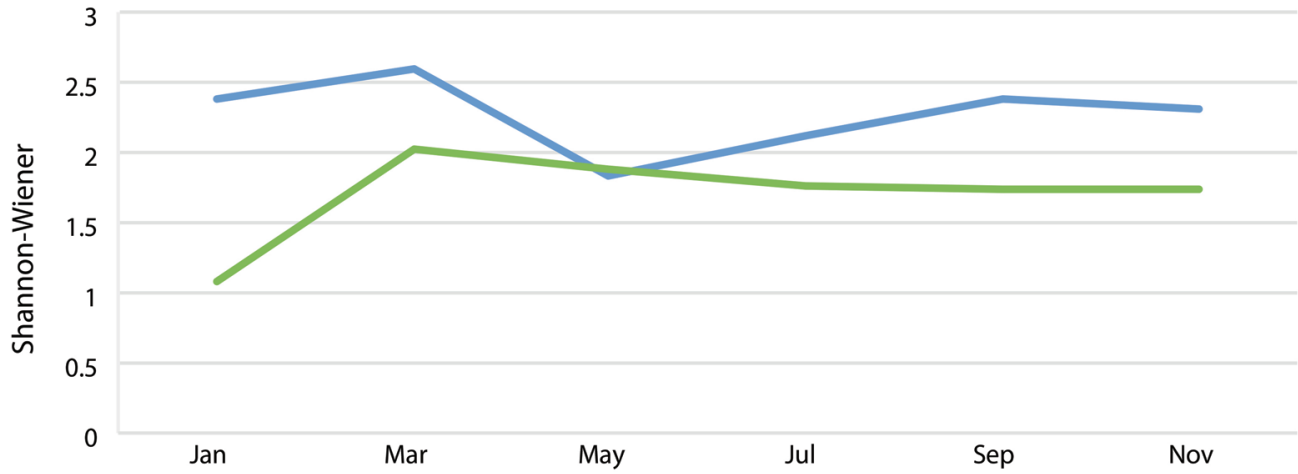

C

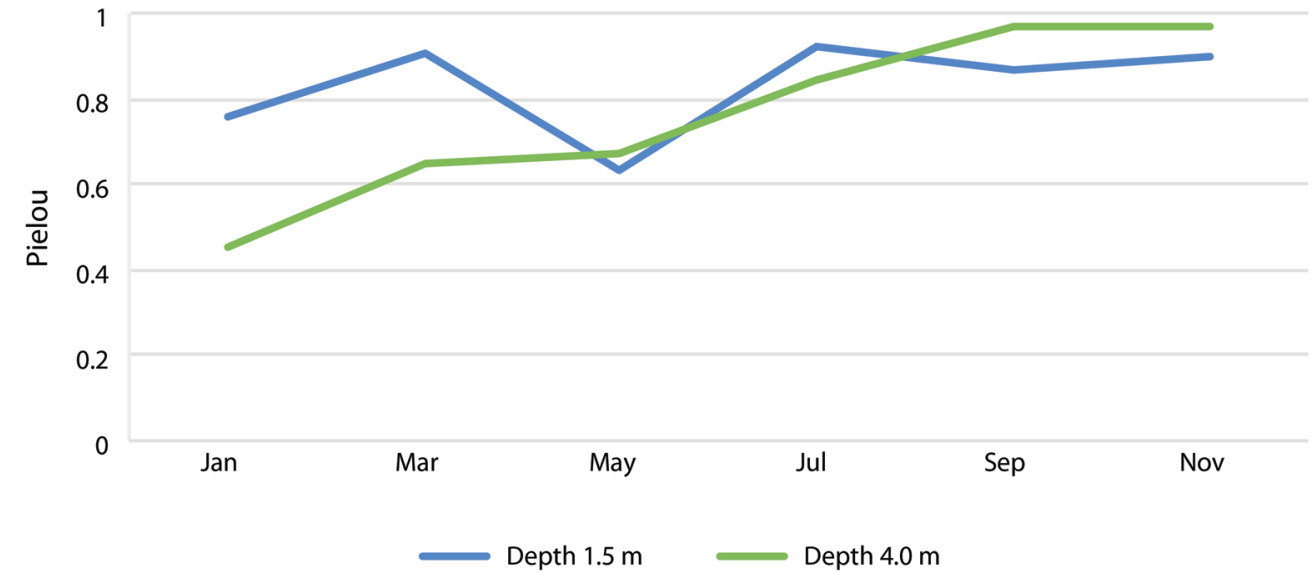

Fig. 1. Polychaete abundance at depths of 1.5 and $4.0 \mathrm{~m}$, and monthly cumulative precipitation (station CEDRES) along 2015. January, September and November: dry season; March, May and July: rainy season (Source: Agência Executiva de Gestão das Águas do Estado da Paraíba [AESA/PB], 2018). 
TABLE 2

Results of PERMANOVA for the total abundance of polychaetes, testing the factors Depth (1.5 and $4.0 \mathrm{~m})$ and Month.

\begin{tabular}{lcccccc}
\multicolumn{1}{c}{ Source } & df & Sum of Squares & Mean Square & Pseudo-F & P(perm) & Unique perms \\
Depth & 1 & 2054.10 & 2054.10 & 1.56 & 0.26 & 975 \\
Month & 5 & 22981.00 & 4596.30 & 3.50 & 0.11 & 997 \\
Residual & 5 & 6563.40 & 1312.70 & & & \\
Total & 11 & 31599.00 & & & & \\
\hline
\end{tabular}

Regarding the polychaete assemblage composition we found differences between months (2-way PERMANOVA, factor Month: Pseudo-F $=2.21$, p-perm $=0.02$, Table 3). Samples from January and May from both depths and from March from in $4.0 \mathrm{~m}$ alone clustered, despite being from different seasons (Fig. 2). No differences were found per depth (2-way PERMANOVA, $\mathrm{p}>0.01$ ). The most abundant species throughout the year was Eunice wasinensis, with a total of 280 individuals (38.2 \% of the total abundance). Other common species that appeared in all sampling dates were Eurythoe complanata, Eunice biannulata, E. wasinensis, Lysidice ninetta, Oxydromus pugettensis and Ceratonereis (Ceratonereis) singularis (Tab. 1). Eunice wasinensis was the most abundant species in January (61 individuals) and May (45), at the depth of $1.5 \mathrm{~m}$. In May, Terebella plagiostoma

TABLE 3

Results of PERMANOVA for the species composition of polychaetes, testing the factors Depth (1.5 and $4.0 \mathrm{~m})$ and Month.

\begin{tabular}{lcccccc}
\multicolumn{1}{c}{ Source } & df & Sum of Squares & Mean Square & Pseudo-F & P(perm) & Unique perms \\
Depth & 1 & 2465.40 & 2465.40 & 1.41 & 0.27 & 967 \\
Month & 5 & 19281.00 & 3856.10 & 2.21 & 0.02 & 998 \\
Residual & 5 & 8711.80 & 1742.40 & & & \\
Total & 11 & 30458.00 & & & & \\
\hline
\end{tabular}

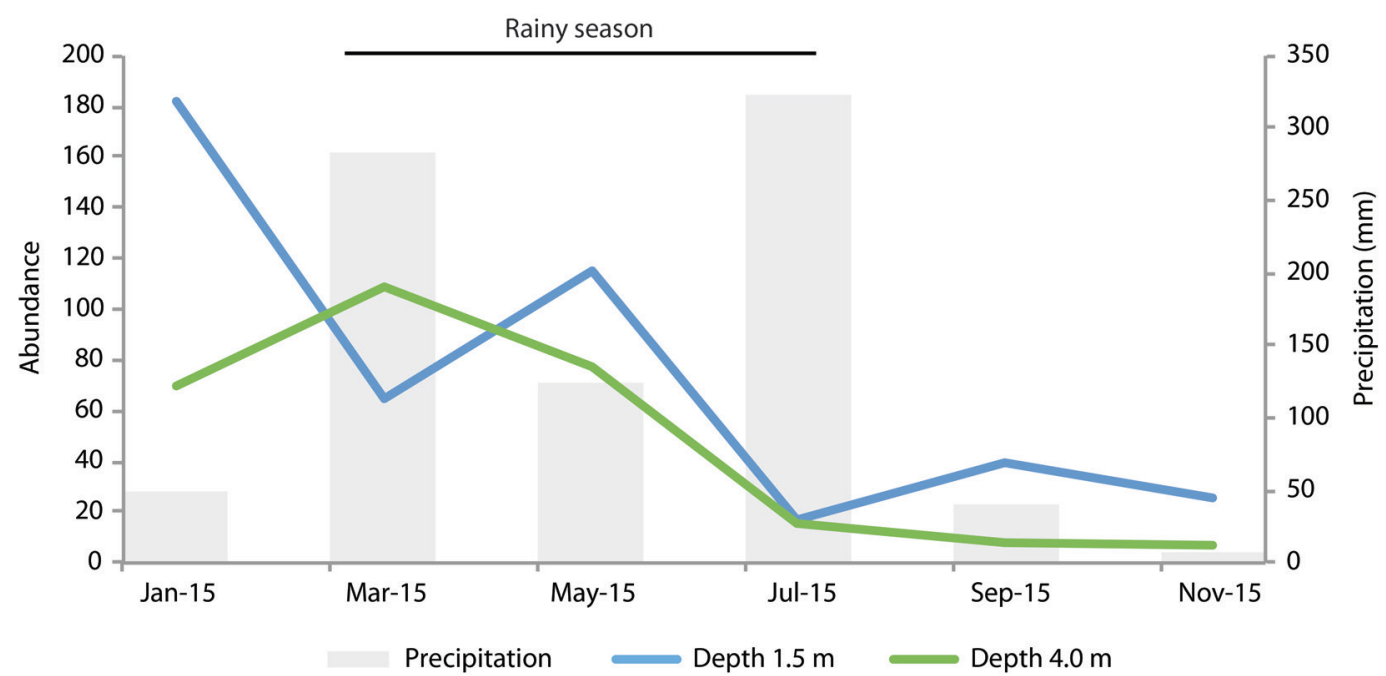

Fig. 2. Principal Coordinates Analysis (PCoA) of polychaete species composition with indication of the tested months within each season, and depths, in the rhodoliths beds of Seixas Beach. 
TABLE 4

Results of PERMANOVA of Shannon-Wiener diversity of polychaetes, testing the factors Depth (1.5 and $4.0 \mathrm{~m})$ and Month.

\begin{tabular}{lcccccc}
\multicolumn{1}{c}{ Source } & df & Sum of Squares & Mean Square & Pseudo-F & P(perm) & Unique perms \\
Depth & 1 & 0.94 & 0.94 & 9.49 & 0.02 & 981 \\
Month & 5 & 0.38 & $7.62 \mathrm{E}-2$ & 0.77 & 0.59 & 998 \\
Residual & 5 & 0.49 & $9.87 \mathrm{E}-2$ & & & \\
Total & 11 & 1.81 & & & & \\
\hline
\end{tabular}

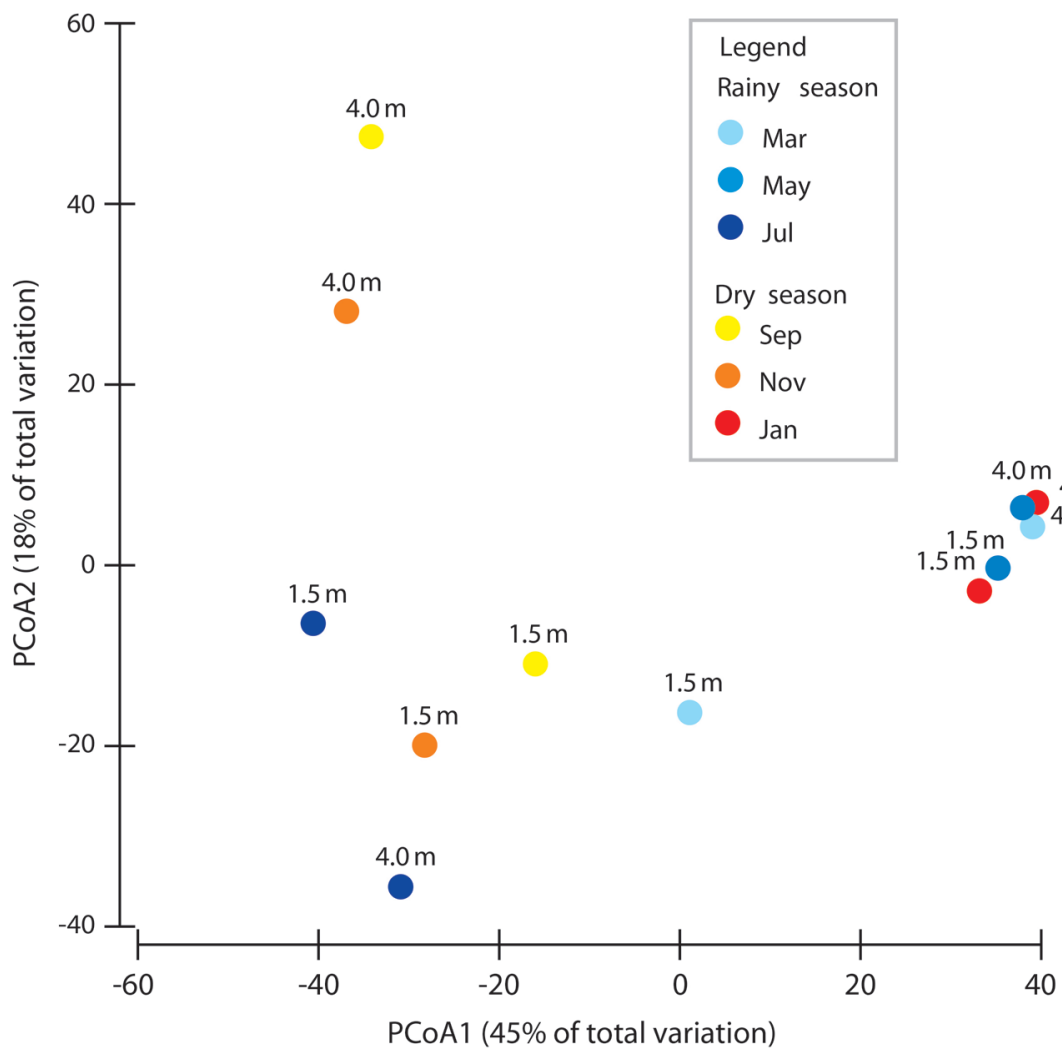

Fig. 3. Variation of diversity indices values for the polychaete assemblage associated to rhodolith beds at Seixas Beach, during 2015 at depths of 1.5 and $4.0 \mathrm{~m}$.

(29 individuals) and E. guanica (18) were also abundant. On the other hand, at the depth of $4.0 \mathrm{~m}$, E. wasinensis was the most abundant species in January, March, and May (53, 58 and 41 individuals, respectively).

Regarding diversity, the values of all indices showed a similar variation trend at both depths, and there was no clear pattern in relation to monthly variations (Fig. 3). Still, there was a tendency for higher values of all diversity indices to occur at the depth of 1.5 $\mathrm{m}$, particularly in January. Yet, differences only occurred for depth in the Shannon-Wiener values (PERMANOVA - Depth: Pseudo-F = 9.49, $p=0.02$, Table 4 ), which were generally higher at the $1.5 \mathrm{~m}$ depth (Fig. 3). For the other indices and seasons, there were no significant differences ( $p>0.01$, Table 5). Regarding Pielou's evenness, values tended to increase along the year (Fig. 3). 
TABLE 5

Results of PERMANOVA of Pielou diversity of polychaetes, testing the factors

Depth (1.5 and $4.0 \mathrm{~m})$ and Month.

\begin{tabular}{lcccccc}
\multicolumn{1}{c}{ Source } & df & Sum of Squares & Mean Square & Pseudo-F & P(perm) & Unique perms \\
Depth & 1 & 0.02 & 0.02 & 1.06 & 0.36 & 962 \\
Month & 5 & 0.20 & 0.04 & 2.56 & 0.18 & 997 \\
Residual & 5 & 0.08 & 0.02 & & & \\
Total & 11 & 0.29 & & & & \\
\hline
\end{tabular}

\section{DISCUSSION}

Our study showed that Eunicidae was the dominant family in the sampled rhodolith beds, E. wasinensis being the most abundant species throughout the study period, mainly at the deeper depth. Batista (2004) found a similar pattern when studying the polychaete fauna of rhodoliths in Cabo Branco Beach (close to the Seixas Beach): $68 \%$ of the total abundance corresponded to the Eunicidae. This eunicid dominance, a taxon composed mostly of detritivores (Jumars, Dorgan, \& Lindsay, 2015), has been associated with degraded habitats, a consequence of the presence of a large quantity of decomposing organic detritus from the reef substrate (Santa-Isabel, Leão, \& PesoAguiar, 2000). However, other studies have also observed the mutualism between eunicid polychaetes and reef habitats, acting as reef aggregating agents (Roberts, 2005). So the dominance of eunicids in our study may be a reflection of such mutualism, and not necessarily the result of a degraded habitat. The presence of the genus Syllis spp. in the Seixas Beach, particularly in the depth $1.5 \mathrm{~m}$, supports this generalization, since Syllis "sensu lato" has been described as sensitive or non-tolerant to organic pollution (Bellan, 1980; Surugiu, 2005). In temperate regions, such as in the Western Mediterranean (Iberian Peninsula), eunicids are also among the most represented polychaete families (Giménez-Casalduero et al., 2001). On the other hand, a study done along the littoral of Spain (along the coast of Catalonia) indicated the prevalence of Syllidae (with circa $31 \%$ of the total) and Serpulidae (approximately $12 \%$ of the total) (Martín, 1987; Berlandi et al., 2012).
The number of species of polychaetes found at Seixas was generally higher than that reported from other tropical areas. These numbers range between nine and 19 families, comprising usually less than 27 species (Batista 2004; Metri, 2006; Neves, 2011). The exception is represented by the paper of Riul (2007), in which at least 34 different families were found. These differences may be attributed, in part, to sampling procedures (e.g. periodicity), and to morphological differences in the algal composition (Berlandi et al., 2012). In addition, rhodoliths may be colonized by Bryozoa, Hydrozoa, Porifera and others taxa, which may, in turn, compete with polychaetes for the available space (Berlandi et al., 2012). Still, the generally higher number of species in this study suggests that, despite the gradual increase of tourism pressure at Seixas Beach, their rhodolith beds still present high polychaete diversity, associated with a good preservation of the beds.

Regarding comparisons of the present data, our initial hypothesis was that the $4.0 \mathrm{~m}$ depth would be more subjected to tourism pressure, due to the presence of vessels, anchoring on the coral reefs and diving activities, and therefore would have lower diversity and abundance. In addition, we speculated that the dry season would also be more subjected to disturbance, since tourism pressure is more intensified during this season (Melo et al., 2014). Our results, however, were only partially congruent with these hypotheses. There were no differences in the total abundance, species richness, and Pielou values of the assemblages of polychaetes, when comparing depths and months. For the species composition there were significant differences per month, but these did not affect the whole dry season, since the species 
composition was more similar for the months from January (dry), March and May (rainy). For the Shannon-Wiener index alone, values were significantly higher in the shallower depth, $1.5 \mathrm{~m}$, which is compelling with our initial hypothesis. The Pielou index was lower in the depth of $4.0 \mathrm{~m}$ than in $1.5 \mathrm{~m}$ for January and March, suggesting less even assemblages, mainly due to the dominance of $E$. wasinensis in the deeper region. During the following months, Pielou evenness increases, suggesting a homogenous distribution of abundance among species. However, abundance was also extremely low. As mentioned, part of the tourism pressure on the beach is due to catamaran traffic and anchoring, whose influence is likely to be more intense at the depth of 4.0 m (Melo, Lins, \& Eloy, 2014; Melo, Crispim, Lima, \& Nishida, 2006), and may therefore be contributing to differences between depths. Yet these differences were only found for a single descriptor and were not found between seasons, suggesting that the higher tourism pressure expected during the dry season does not affect the polychaete assemblage. The relatively high evenness throughout the whole study also suggests that abundance is regularly distributed among different taxa along the year.

Overall, based on these results, we are not able to conclude that there is a potential negative effect of tourism on the polychaete assemblage associated to the rhodolith beds at the Seixas Beach.However, our results refer to a single beach (without spatial replication) and this cannot be extrapolated for a wider geographical range. More information (comparisons of different beaches with different tourism pressures) and other formal tourism indicator measurements are needed in order to reach more solid conclusions on the effects of tourism. Their impact may be quite high in Brazil, but this effect is generally not being monitored. Also, wider and long-term monitoring programs are needed throughout the Brazilian coast to identify diversity patterns and what may be affecting these in order to better preserve the rhodolith beds (Horta et al., 2016). The present study nevertheless contributes to increase the knowledge of the polychaete diversity associated with rhodolith beds in tropical areas, and highlights the need for more knowledge and studies on the impacts of local stressors on these assemblages.

Ethical statement: authors declare that they all agree with this publication and made significant contributions; that there is no conflict of interest of any kind; and that we followed all pertinent ethical and legal procedures and requirements. All financial sources are fully and clearly stated in the acknowledgements section. A signed document has been filed in the journal archives.

\section{ACKNOWLEDGEMENTS}

This study was financed in part by the "Coordenação de Aperfeiçoamento de Pessoal de Nível Superior - Brasil (CAPES)" Finance Code 001. The authors acknowledge the facilities provided by the "Universidade Federal da Paraíba" (Campus I), such as the availability of the "Laboratório de Invertebrados Paulo Young" (LIPY). They acknowledge the academic support provided by "Programa Regional de Pós-Graduação em Desenvolvimento e Meio Ambiente" (PRODEMA). Thanks to Prof. Dr. Ricardo Rosa (UFPB) for the supervision of the present work. D.A.C. thanks the Ph.D. scholarship provided by "Fundação de Apoio à Pesquisa do Estado da Paraíba" (FAPESQ) in partnership with CAPES. M.L.C. thanks the productivity grant provided by the "Conselho Nacional de Desenvolvimento Científico e Tecnológico" (CNPq).

\section{RESUMEN}

\section{¿El turismo está afectando a los conjuntos de poliquetos asociados con los fondos de rodolitos en el Nordeste de Brasil?}

Introducción: Rodolitos son estructuras biogénicas distribuidas en todo el mundo, formadas por varios tipos de algas calcáreas. Pueden albergar una gran diversidad de invertebrados marinos, entre los cuales los poliquetas son representantes conspicuos y diversificados. No obstante, 
los fondos de los rodolitos son vulnerables a varias actividades humanas (por ejemplo, la explotación de especies comerciales asociadas con rodolitos, exploración petrolera, actividades de pesca, descargas de efluentes y turismo), que pueden comprometer esa diversidad. El turismo está aumentando su impacto en los fondos de rodolitos. El calentamiento global y la acidificación de los océanos también son factores determinantes en el cambio de fauna. Objetivo: El presente estudio tuvo como objetivo analizar los conjuntos de poliquetos asociados con fondos de rodolitos sujetos a diferentes intensidades de presión turística en la playa de Seixas (Nordeste de Brasil), donde el turismo está aumentando gradualmente con el tiempo. Métodos: Los efectos fueron evaluados a dos profundidades, $1.5 \mathrm{~m}$ y $4.0 \mathrm{~m}$. El muestreo se realizó cada dos meses durante 2015, abarcando las dos estaciones marcadas del año en la región (lluviosa y seca). Se colocaron cuadrantes de 15 x $15 \mathrm{~cm}$ en cada profundidad durante el muestreo. Se recolectaron todos los rodolitos presentes dentro del cuadrante (generalmente de four a five rodolitos). Nuestra hipótesis era que la mayor profundidad y las muestras de la estación seca estarían cada vez más sujetas al impacto del turismo. Resultados: En total, se encontraron 49 especies (de 21 familias diferentes) y se recolectó un total de 733 individuos. La especie más abundante fue Eunice wasinensis (280 individuos, $38.2 \%$ de la abundancia total). La especie Eurythoe complanata, Eunice biannulata, E. wasinensis, Lysidice ninetta, Oxydromus pugettensis y Ceratonereis (Ceratonereis) singularis aparecieron en todos los meses. El estudio detectó una tendencia a mayor diversidad en la profundidad de 1,5 m para todos los índices, pero solo los valores de Shannon-Wiener fueron significativamente mayores allí $(\mathrm{p}<0.05)$. No se encontraron diferencias con respecto a los meses. Conclusiones: Estos resultados sugieren que puede haber una mayor presión potencial debido al turismo a $4.0 \mathrm{~m}$ debido a actividades de embarcaciones más intensas (tráfico de catamaranes que transportan turistas hacia y desde los arrecifes) en esa área. Nuestros resultados aumentan nuestro conocimiento sobre la diversidad de poliquetos asociados con los fondos de rodolitos en áreas tropicales, y resaltan la necesidad de estudios de monitoreo para probar el impacto de los factores de estrés locales en estos conjuntos.

Palabras clave: Annelida, Catamaranes, Perturbaciones, Sustrato duro, Costa tropical.

\section{REFERENCES}

Agência Executiva de Gestão das Águas do Estado da Paraíba. (2018). Retrieved from http://www.aesa. pb.gov.br/.

Aguirre, J., Braga, J. C., \& Bassi, D. (2017). Rhodoliths and Rhodolith Beds in the Rock Record. In R. Riosmena-Rodríguez, W. Nelson \& J. Aguirre (Eds.).
Rhodolith/Maërl Beds: A Global Perspective (pp. 105-138). Boca Raton, USA: Springer.

Alvares, C. A., Stape, J. L., Sentelhas, P. C., Gonçalves, J. L. M., \& Sparovek, G. (2013). Köppen's climate classification map for Brazil. Meteorologische Zeitschrift, 22(6), 711-728.

Amado-Filho, G. M., Moura, R. L., Bastos, A. C., Salgado, L. T., Sumida, P. Y., Guth, A. Z., ... Thompson, F. L. (2012). Rhodolith beds are major $\mathrm{CaCO}_{3}$ biofactories in the Tropical South West Atlantic. PLoS ONE, 7(4), 1-6. e35171.

Amado-Filho, G. M., \& Pereira-Filho, G. H. (2012). Rhodolith beds in Brazil: a new potential habitat for marine bioprospection. Brazilian Journal of Pharmacognosy, 22(4), 782-788.

Amaral, A. C. Z., \& Nonato, E. F. (1994). Anelídeos poliquetos da costa brasileira. 5. Pisionidae, Chrysopetalidae, Amphinomidae e Euphrosinidae. Revista Brasileira de Zoologia, 11(2), 361-390.

Anderson, M. J., Gorley, R. N., \& Clarke, K. R. (2008). PERMANOVA+ for PRIMER: Guide to Software and Statistical Methods. Plymouth, England: PRIMER-E.

Barroso, R., \& Paiva, P. C. (2007). Amphinomidae (Annelida: Polychaeta) from Rocas atoll, Northeastern Brazil. Arquivos do Museu Nacional, Rio de Janeiro, 65(3), 357-362.

Batista, J. B. (2004). A comunidade de Lithothamnium sp Philippi, 1837 (Rhodophyta - Corallinaceae), na praia do Cabo Branco, João Pessoa, Paraíba, Brasil (Graduation monograph). João Pessoa, Brazil: Federal University of Paraíba.

Bellan, G. (1980). Relationship of pollution to rocky substratum polychaetes on the French Mediterranean coast. Marine Pollution Bulletin, 11, 318-321.

Berlandi, R. M., Figueiredo, M. A. O., \& Paiva, P. C. (2012). Rhodolith Morphology and the Diversity of Polychaetes Off the Southeastern Brazilian Coast. Journal of Coastal Research, 28, 280-287.

Blake, J. A., Hilbig, B., \& Scott, P. H. (1995). Taxonomic atlas of the benthic fauna of the Santa Maria basin and the Western Santa Barbara Channel, Volume 5. The Annelida Part 2, Polychaeta: Phyllodocida (Syllidae and scale-bearing families), Amphinomida, and Eunicida. Santa Barbara, USA: Santa Barbara Museum of Natural History.

Blake, J. A., Hilbig, B., \& Scott, P. H. (1996). Taxonomic atlas of the benthic fauna of the Santa Maria basin and the Western Santa Barbara Channel, Volume 6. The Annelida Part 3, Polychaeta: Orbiniidae to 
Cossuridae. Santa Barbara, USA: Santa Barbara Museum of Natural History.

Blake, J. A., Hilbig, B., \& Scott, P. H. (1997). Taxonomic atlas of the benthic fauna of the Santa Maria basin and the Western Santa Barbara Channel, Volume 4. The Annelida Part 1, Oligochaeta and Polychaeta: Phyllodocida (Phyllodocidae to Paralacydoniidae) (rev. ed.). Santa Barbara, USA: Santa Barbara Museum of Natural History.

Böggemann, M. (2009). Polychaetes (Annelida) of the abyssal SE Atlantic. Organisms Diversity \& Evolution, 9, 251-428.

Bosence, D. W. J. (1979). Live and dead faunas from coralline algal graves, Co. Galway. Palaeontology, 22(2), 449-478.

Bruno, J. F., \& Bertness, M. D. (2001). Habitat modification and facilitation in benthic marine communities. In M. D. Bertness, S. D. Gaines \& M. E. Hay (Eds.). Marine Community Ecology (pp. 201-218). Sunderland, USA: Sinauer Associates.

Camargo, M. G., \& Lana, P. C. (1995). Lumbrineridae (Polychaeta: Eunicemorpha) da costa sul e sudeste do Brasil. II. Lumbrineris. Iheringia, Série Zoologia, 79, 93-120.

Capa, M. (2003). Estudio de la criptofauna coralina y de los anélidos poliquetos (Annelida: Polychaeta) de substratos duros del Parque Nacional de Coiba, Panamá (Doctoral thesis). Madrid, Spain: Universidad Autónoma de Madrid.

Clarke, K. R., Gorley, R. N., Somerfield, P. J., \& Warwick, R. M. (2014). Change in marine communities: an approach to statistical analysis and interpretation $\left(3^{\circ}\right.$ ed.). Plymouth, England: PRIMER-E.

Costa, D. A. (2016). Assembleias de poliquetas (Annelida), associados aos rodolitos (Corallinophycidae, Rhodophyta), na praia do Seixas, João Pessoa, Paraíba, Brasil (Master's thesis). Rio Tinto, Brazil: Federal University of Paraíba.

Costa, D. A., De Assis, J. E., \& Christoffersen, M. L. (2008). New synonym of Hesione splendida (Hesionidae, Polychaeta, Annelida). Biociências, 16(2), 131-133.

Day, J. H. (1967a). A monograph on the Polychaeta of Southern Africa, Part 1. Errantia. London, England: Trustees of the British Museum (Natural History).

Day, J. H. (1967b). A monograph on the Polychaeta of Southern Africa, Part 2. Sedentaria. London, England: Trustees of the British Museum (Natural History).
De Assis, J. E., Samiguel, C. A., \& Christoffersen, M. L. (2007). Two new species of Nicomache (Polychaeta: Maldanidae) from the Southwest Atlantic. Zootaxa, 1454, 27-37.

Fauchald, K. (1977). Polychaetes from intertidal areas in Panama, with a review of previous shallow-water records. Smithsonian Contributions to Zoology, 221, $1-81$

Fauchald, K. (1992). A review of the genus Eunice (Polychaeta: Eunicidae) based upon type material. Smithsonian Contributions to Zoology, 523, 1-422.

Foster, M. S. (2001). Rhodoliths: between rocks and soft places. Journal of Phycology, 37, 659-667.

Foster, M. S., McConnico, L. M., Lundsten, L., Wadsworth, T., Kimball, T., Brooks, L. B., ... Steller, D. L. (2007). Diversity and natural history of a Lithothamnion muelleri-Sargassum horridum community in the Gulf of California. Ciencias Marinas, 33(2), 367-384.

G1 Paraíba. (2016). Número de turistas que visitaram a $P B$ cresceu 4,52\% em 2015, diz PBtur. Retrieved from http://g1.globo.com/pb/paraiba/noticia/2016/01/ numero-de-turistas-que-visitaram-pb-cresceu452-em-2015-diz-pbtur.html.

Giangrande, A., Delos, A. L., Musco, L., Licciano, M., \& Pierri C. (2004). Polychaete assemblages of rocky shore along the South Adriatic coast (Mediterranean Sea). Cahiers de Biologie Marine, 45, 85-95.

Giangrande, A., Licciano, M., \& Musco, L. (2005). Polychaetes as environmental indicators revisited. Marine Pollution Bulletin, 50, 1153-1162.

Giménez-Casalduero, F., Rodríguez-Ruiz, S., Vivas, M., \& Ramos-Esplá, A. A. (2001). Variaciones de las características estructurales de la comunidad de poliquetos asociada a dos fondos de maërl del litoral alicantino (sudeste de la península Ibérica). Boletín del Instituto Español de Oceanografia, 17(1/2), 191-201.

Hinojosa-Arango, G., \& Riosmena-Rodríguez, R. (2004). Influence of Rhodolith-Forming Species and GrowthForm on Associated Fauna of Rhodolith Beds in the Central-West Gulf of California, México. Marine Ecology, 25(2), 109-127.

Horta, P. A., Berchez, F. A. S., Nunes, J. M. C., Scherner, F., Pereira, S. M. B., Riul, P., ... Figueiredo, M. (2015). Monitoramento de banco de rodolitos. In A. Turra \& M. R. Denadai (Eds.). Protocolos para o Monitoramento de Habitats Bentônicos Costeiros (pp. 48-61). São Paulo, Brazil: Instituto Oceonográfico da Universidade de São Paulo.

Horta, P. A., Riul, P., Amado-Filho, G. M., Gurgel, C. F. D., Berchez, F., Nunes, J. M. C., ... Figueiredo, M. (2016). Rhodoliths in Brazil: Current knowledge and 
potential impacts of climate change. Brazilian Journal of Oceanography, 64(Suppl. 2), 117-136.

Instituto Brasileiro de Petróleo, Gás e Biocombustíveis. (2014). Estado da arte sobre estudos de Rodolitos no Brasil. Relatório Final. Rio de Janeiro, Brazil: Instituto Brasileiro de Petróleo, Gás e Biocombustíveis (IBP).

Jumars, P. A., Dorgan, K. M., \& Lindsay, S. M. (2015). Diet of worms emended: an update of polychaete feeding guilds. Annual Review of Marine Science, 7, 497-520.

Knox, G. A. (1977). The role of polychaetes in benthic soft-bottom communities. In D. Reish \& K. Fauchald (Eds). Essays on polychaetous annelids in memory of Dr. Olga Hartman (pp. 547-604). Los Angeles, USA: Allan Hancock Foundation.

Lima, P. J., \& Heckendorff, W. D. (1985). Climatologia. In Governo do Estado da Paraíba (Ed.). Secretaria da Educação, Universidade Federal da Paraíba. Atlas Geográfico do Estado da Paraíba (pp. 34-43). João Pessoa, Brazil: Grafset.

Martín, D. (1987). La comunidad de anélidos poliquetos de las concreciones de algas calcáreas del litoral catalán. Caracterización de las especies. Publicaciones del Departamento de Zoología, Universidad de Barcelona, 13, 45-54.

Melo, R. S., Crispim, M. C., Lima, E. R. V., \& Nishida, A. K. (2006). Estimated recreational carrying capacity of reef environments at Seixas Beach in the state of Paraíba, Brazil. Turismo - Visão e Ação, 8(3), 411-422.

Melo, R. S., Crispim, M. C., Viana, E. R., \& Lins, R. P. (2008). Planejamento turístico e zoneamento ambiental: um estudo de caso nos ambientes recifais das praias do Seixas, Penha e Arraial - PB. Caderno Virtual de Turismo, 8(2), 23-33.

Melo, R. S., Lins, R. P. M., \& Eloy, C. C. (2014). O impacto do turismo em ambientes recifais: caso praia Seixas-Penha, Paraíba, Brasil. Revista Eletrônica do Prodema, 8, 67-83.

Metri, R. (2006). Ecologia de um banco de algas calcárias da Reserva Biológica Marinha do Arvoredo, SC, Brasil (Doctoral thesis). Curitiba, Brazil: Federal University of Paraná.

Nelson, W. A. (2009). Calcified macroalgae - critical to coastal ecosystems and vulnerable to change: a review. Marine and Freshwater Research, 60, 787-801.

Neves, S. B. (2011). Colonização da macrofauna bentônica em rodolitos presentes na praia Portal de Santa
Cruz, Aracruz-ES. (Graduation monograph). Vitória, Brazil: Federal University of Espírito Santo.

Nonato, E. F., \& Luna, J. A. C. (1970). Anelídeos poliquetas do Nordeste do Brasil. I - Poliquetas bentônicos da costa de Alagoas e Sergipe. Boletim do Instituto Oceanográfico, São Paulo, 19, 57-130.

Otero-Ferrer, F., Mannarà, E., Cosme, M., Falace, A., Montiel-Nelson, J. A., Espino F., ... Tuya, F. (2018). Early-faunal colonization patterns of discrete habitat units_A case study with rhodolith-associated vagile macrofauna. Estuarine, Coastal and Shelf Science, 218, 9-22.

Paiva, P. C. (1993). Anelídeos poliquetas da plataforma continental norte do Estado de São Paulo: I - Padrões de densidade e diversidade específica. Boletim do Instituto Oceanográfico, São Paulo, 41(1/2), 69-80.

Prata, J., Costa, D. A., Manso, C. L. C., Crispim, M. C., \& Christoffersen, M. L. (2017). Echinodermata associated to rhodoliths from Seixas Beach, State of Paraíba, Northeast Brazil. Biota Neotropica, 17(3), 1-11.

R Core Team. (2018). R: A language and environment for statistical computing. $R$ Foundation for Statistical Computing, Vienna, Austria. Retrieved from https:// www.R-project.org/.

Reish, D. J. (1979). Bristle worms (Annelida: Polychaeta). In C. W. Hart \& S. L. H. Fuller (Eds.). Pollution Ecology of Estuarine Invertebrates (pp. 77-125). New York, USA: Academic Press.

Riosmena-Rodríguez, R., Nelson, W., \& Aguirre, J. (2017). Rhodolith/Maërl Beds: A global perspective (v. 15), Boca Raton, USA: Springer.

Riul, P. (2007). Aspectos da biologia e ecologia de rodolitos e comunidade associada na grande João Pessoa, $P B$. (Master's thesis). João Pessoa, Brazil: Federal University of Paraíba.

Riul, P., Lacouth, P., Pagliosa, P. R., Christoffersen, M. L., \& Horta, P. A. (2009). Rhodolith beds at the easternmost extreme of South America: community structure of an endangered environment. Aquatic Botany, 90(4), 315-320.

Roberts, J. M. (2005). Reef-aggregating behaviour by symbiotic eunicid polychaetes from cold-water corals: do worms assemble reefs? Journal of the Marine Biological Association of the United Kingdom, 85, 813-819.

Samuelson, G. M. (2001). Polychaetes as indicators of environmental disturbance on Subartic Tidal Flats, Iqaluit, Baffin Island, Nunavut territory. Marine Pollution Bulletin, 9, 773-741. 
Santa-Isabel, L. M., Leão, Z. M. A. N., \& Peso-Aguiar, M. C. (2000). Polychaetes from the Guarajuba coral reefs, Bahia, Brazil. Bulletin of Marine Science, 67, 645-653.

Santos, C. S. G., \& Lana, P. C. (2003). Nereididae (Polychaeta) da costa Nordeste do Brasil. III. Gêneros Ceratonereis e Nereis. Iheringia, Série Zoologia, 93, 5-22.

Surugiu, V. (2005). The use of polychaetes as indicators of eutrophication and organic enrichment of coastal waters: a study case - Romanian Black Sea coast.
Analele Ştiinţifice ale Universităţii “Al.I. Cuza” Iaşi, s. Biologie animală, 51, 55-62.

Uebelacker, J. M., \& Johnson, P. G. (1984). Taxonomic guide to the polychaetes of the Northern Gulf of Mexico. Final report to the Minerals Management Service, contract 14-12-001-29091. Mobile, USA: Barry A. Vittor \& Associates.

Viéitez, J. M., Alós, C., Parapar, J., Besteiro, C., Moreira, J., Núñez, J., ... San Martín, G. (2004). Fauna Ibérica. Annelida Polychaeta I (v. 25). Madrid, Spain: Museo Nacional de Ciencias Naturales, Consejo Superior de Investigaciones Científicas (CSIC). 